\title{
Serendipity and International Experience in Political Science: The Bulgaria/Southern Illinois University at Carbondale Connection
}

\author{
Albert P. Melone, Southern Illinois University at Carbondale
}

Grant taught that research in a given area should move systematically from a review of the existing literature to the testing of specific hypotheses. One's research focus should proceed from identifying a serious question through the nooks and crannies of anomalies and counterpropositions. Yet, sometimes professional activity can take on a serendipitous quality that violates the canons of conventional research. The vagaries of world events often compel political scientists to refocus their scholarly attention. This combined with opportunities born of an institutional commitment to an international perspective may raise questions that on first sight are only tangentially related to our primary research focus. Happily, the result may be a richer professional life and the promise of a more explanatory political science.

Since my graduate school days in the late 1960 s, I was aware of the importance of conducting comparative research. Although my primary focus since then has been on judicial politics and related topics in American politics, I had long ago internalized the view that the comparative method is essential if, as a discipline, we are to develop a science of politics. But how does one move from an exclusive attention on the U.S. scene to other political cultures? As my case illustrates, it can happen when there is a combination of a university support system that encourages international exchanges, changing world events, and the good fortune of being in the right place at the right time.

The relationship between Southern Illinois University at Carbondale (SIUC) and the Republic of Bulgaria began in 1981. The late Horace B. Jacobini, professor of political science, visited Bulgaria while on a Fulbright in Romania. At an international conference, he met Dr. Emilia Kandeva Spiri- donova of the Bulgarian Institute for State and Law. She subsequently received a Fulbright grant to study at SIUC during the 1983-84 academic year.

During her stay in Carbondale, Spiridonova became interested in principles of public administration as understood by American scholars. This interest has culminated in a widely read and influential book published in Bulgaria two years ago. Today, Spiridonova is the director of the Center for Administration, a newly created government agency. In the last two years, personnel of this organization have hosted visits and provided support to SIUC public administration scholars.

During her spring 1984 visit to the SIUC campus, Spiridonova arranged for a campus visit by two representatives of the Bulgarian Embassy. The outgrowth of that visit was the formulation and signing of a Memorandum of Understanding between the Bulgarian Council of Higher Education and SIUC. The first visitor to SIUC under this linkage agreement was Professor Matey Mateev. He spent one month working with colleagues in the Department of Physics. Following the demise of the old regime in November 1989, Mateev became the first Minister of Public Education in the new government.

As a result of several visits by SIUC administrators to Bulgaria, a proposal was submitted to the United States Information Agency (USIA) under the University Affiliations Program. This proposal was funded for the period 1987 to 1991 , and resulted in the exchange of nine SIUC faculty and nine Bulgarian researchers and faculty. Exchanges were conducted in the areas of law, sociological research, radio-television, higher education administration, educational psychology, and art.

A major result of the grant was the first Annual Bulgarian-American Law Days, sponsored jointly by the Institute of State and Law of Sofia and SIUC. The theme of this conference, in May 1991, was the impact of constitutional change on the Bulgarian legal and political system. Three political science professors, three law professors, and the SIUC Executive Assistant to the President for International and Economic Development composed the SIUC contingent. ${ }^{1}$ The official and unofficial Bulgarian participants far outnumbered the Americans. They included scholars of the Institute of State and Law, government officials, practicing attorneys, and law professors.

The timing of the Varna conference was particularly fortuitous because it occurred after much of the work of the Grand National Assembly that was fashioning Bulgaria's new constitution had taken place. A new democratic document was promulgated in July 1991 .

Some Bulgarian participants had an intimate knowledge of the politics of constitution-making by virtue of their personal involvement in drafting various provisions. They sometimes argued with one another, providing the American delegation with graphic descriptions and explanations for the likely changes in Bulgaria's political and constitutional system.

Some papers by the American participants were explicitly crosscultural while others focused exclusively on the U.S. experience. The extent to which our Bulgarian hosts understood constitutional issues within a comparative political context was particularly illuminating; their knowledge of alternative constitutional and political systems was remarkable. A volume containing the conference papers was originally scheduled for publication in 1993.2

Two closely related activities resulted from the Varna experience. 
The first was a sequel to the first Bulgarian/American Law Days. The second project is a proposal for the establishment of a Center for Law, Policy Studies, and Culture to be housed in Sofia.

The USIA-funded 1992 Carbondale conference was jointly hosted by the SIUC Law School and the Department of Political Science. The conference theme was the U.S. judicial process and constitutional system.

Some 15 Bulgarian judges and justices at each jurisdictional level, prosecuting attorneys, private lawyers and law professors attended the conference. They were selected because of their probable impact on the future of the Bulgarian judicial system and for their lack of ties to the old regime.

Unlike the previous conference, only the American participants presented papers. These papers became part of a single volume written in English and Bulgarian. ${ }^{3}$

The presence of the Bulgarian jurists on the SIUC campus was an opportunity to examine the problems of judiciaries in a transitional society. All of the Bulgarians were asked to respond to a closed-ended questionnaire and to participate in an additional in-depth personal interview. All but one participant agreed to fill -out the closed-ended questionnaire, and 14 agreed to indepth personal interviews. The closed-item schedule was written in English with a Bulgarian translation.

Composing the interview schedules required a careful look at the new Bulgarian Constitution promulgated in July 1991. To design these interview schedules, two graduate students and I worked closely with a Bulgarian legal scholar, Silvey Chernev. He was in residence at the SIUC Law School during the spring term preceding the conference. Along the way, we gained an appreciation for the extraordinary political acumen and commitment to human rights that went into writing the constitution.

The knowledge gained through these interviews made it possible for us to better understand the principles and politics surrounding various constitutional provisions. We were also able to glimpse whether these jurists believed that a new constitutional system could change existing attitudes. Indeed, a year later we understood the importance of our preliminary research in terms of the new institutionalism movement in political research. Can democratic institutions coax a civil society into existence? The results of the interviews were mixed. With some trepidation and much hope, I now respond in the affirmative that folkways can follow stateways.

During the last days of the Varna conference, the Bulgarian and SIUC delegations talked of a permanent SIUC presence in Bulgaria to study problems of democracy. The result is a proposal for a Center for Law, Policy Studies and Culture in Sofia. The principal activities of the center would include: (a) training government and private sector managers in administrative sciences, (b) training of law, social science and humanities students in law-related subjects, (c) post-graduate education for practicing lawyers, social scientists, and humanists, (d) training of scientific and teaching staff in the fields of law, social science, and the humanities, (e) joint research projects in various areas of Bulgarian-American law, law and social science projects, and cultural studies. The Center will also publish and distribute theoretical and applied studies.

Although the proposal has been well-received in Bulgaria, its implementation has been difficult. We are still negotiating its creation. The success of the project depends upon the receipt of grant funds from private and public foundations.

Even if the proposed Center never becomes a reality, the interest developed on the SIUC campus in Bulgaria justifies the expenditure of our energy. Two public administration specialists received a research grant to study the creation of not-for-profit organizations in Bulgaria. In 1993 they also received a USIA grant to train Bulgarian city administrators. They have lectured extensively in Bulgaria on principles of public administration. ${ }^{4}$ Faculty members in the SIUC colleges of education, business admin- istration, and the school of agriculture have continuing research projects in Bulgaria. Bulgarian students have come to SIUC to study everything from art to mathematics. The department of political science currently has enrolled six students; four Bulgarians are pursuing MPA degrees.

As for my own research activity, in October 1992 I presented a paper at a Conference on Legal Education and the New Democratic Societies-Transition Toward Democracy and the Rule of Law. At that meeting and subsequent stay in Sofia I entertained the counter-conventional idea that Bulgaria could experience a successful transition from totalitarianism to democracy. This might happen though the socalled prerequisites for democracy are not present.

While visiting with colleagues in Sofia after the Blagoevgard conference, the president of one of the many new Bulgarian foundations asked me to pen an article about problems associated with the creation of civil society. 5 At the time I was fixated on the debilitating effects of the twin traps of mass society and the iron law of oligarchy on the creation of pluralism. However, within nine months after writing that piece my attention turned to the more fundamental issue; namely, is it possible to coax a civil society from the rudiments of a democratic constitution without those commonly supposed prerequisites such as a strong economy, a middle class, and experience with democratic institutions such as competitive political parties? This is perhaps the most interesting question in political science today.

Studying the politics surrounding the creation of the July 1991 Bulgarian Constitution provides an avenue to explore this issue. Discovering Giuseppe Di Palma's To Craft Democracies: An Essay on Democratic Transitions (1990) was a useful antidote for the pessimism, for example, in the political development works of Huntington and Dahl. Di Palma's provocative book lays out the contours for understanding how established authorities and their political opponents may accommodate each other to 
produce a peaceful change from authoritarianism or totalitarianism to democracy.

My first serious crack at this issue came in the form of a paper presented at a 1993 professional meeting. ${ }^{6}$ It is a detailed account of Bulgaria's National Roundtable Talks held in late 1989 and early 1990. My sabbatical in the fall of 1993 was devoted to exploring this question further. Among other activities, I interviewed a good number of Bulgarian elites including members of the Grand National Assembly that drafted the July 1991 Constitution and members of the court system including justices of the Constitutional Court.

The cliche is probably true: a little knowledge is dangerous. Yet, this international experience has broadened my understanding of politics in general and has sharpened my analysis of the U.S. system. I now wonder aloud whether it makes better theoretical and practical sense to change the U.S. system of judicial review with its questionable origins, guilt-ridden operation, and divisive politics to some variation on the Western European system of constitutional courts recently adopted in Bulgaria and other former Eastern European bloc states. A constitutional court with a distinct mandate to protect the constitution and human rights from the excesses of willful majorities may be far preferable to what fashion dictates is the appropriate judicial function.

Thus, I have come back to my original preoccupation. However, there is a difference. I ask not what the U.S. experience can teach the world, but what the world can teach U.S. citizens about their own system. In my case, a series of serendipitous events together with a university support system that encourages an international perspective provided the opportunity for new insights. As a profession we need to encourage more subject specialists to obtain greater participation in international political science. We will then be in a better position to fulfill the central task of our profession; namely, the discovery of conditional universal propositions.

\section{Notes}

1. The political scientists included Roy Miller, Leland Stauber, and myself. The three participating law professors are Patrick Kelley, Wenona Whitfield, and Dean Harry Haynsworth. Charles Klasek is the SIUC official in charge of International Programs and Economic Development.

2. I am unclear about the publication stage and status of this volume. We have discovered that one of the difficulties in writing for publishers in Bulgaria is the lack of certainty about deadlines.

3. Political scientists David Derge, Michael Esler, John S. Jackson, Diane Schmidt, and myself are contributors. The SIUC law professor contributors include Jill Adams, Keith Beyler, Maria Frankowska, Patrick Kelley, Thomas McAffee, and William Schroeder. The book is: Maria

Frankowska and Albert P. Melone, eds., The Legal System and American Constitutional Democracy (Sofia, Bulgaria: St. Kliment Ohridski University Press, 1993).

By the way, cooperation between political scientists and law professors proved so successful that a joint grant proposal was prepared by the deans of the College of Liberal
Arts (John S. Jackson) and Law School (Harry Haynsworth) and funded by the USIA for the summer of 1993. This time 19 young political scientists and law professors from around the world spent six weeks on campus steeping themselves in the scholarship of American politics and government.

4. Uday Desai and Keith Snavely have twice visited Bulgaria. They are also responsible for bringing to the SIUC campus several Bulgarians who are pursuing M.P.A. degrees.

5. When working in Bulgaria it becomes evident that schedules are not always observed. My piece touted as the lead article of a new journal was scheduled for release in January 1993. As of December 1993 it has not been published. However, in fairness I have had similar experiences with U.S. publishers. The piece is titled "Creating a Civil Society: The Twin Traps of Mass Society and the Iron Law of Oligarchy," Civil Society Journal vol. 1, no. 1, 1994. In Bulgarian.

6. This piece was presented at the 1993 Interim Meeting of the Research Committee on Comparative Judicial Studies, International Political Science Association, St. John's College, Santa Fe, New Mexico, August 1-4, 1993. It is titled: Bulgaria's $\mathrm{Na}$ tional Roundtable Talks and the Politics of Accommodation: Creating the Conditions for a Peaceful Transition to a Democratic Constitutional System. This piece has been accepted for publication in the July 1994 issue of International Political Science Review.

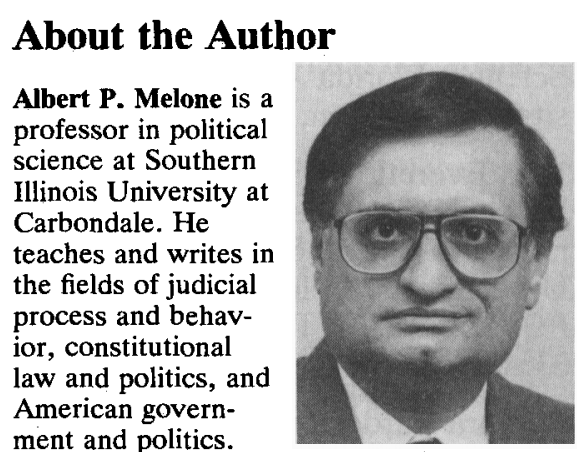

